\title{
Past and current geochemical conditions influence silicon isotope signatures of pedogenic clay minerals at the soil profile scale, Ethiopia
}

\author{
J.-T. Cornelis ${ }^{\mathrm{a}, \mathrm{b}, \mathrm{c}, *}$, D. Weis ${ }^{\mathrm{a}}$, S. Opfergelt ${ }^{\mathrm{c}}$, E. Van Ranst ${ }^{\mathrm{d}}$, M. Dumon ${ }^{\mathrm{d}}$ \\ ${ }^{\text {a }}$ Pacific Centre for Isotopic and Geochemical Research, Department of Earth, Ocean and Atmospheric Sciences, University of British Columbia (UBC), 6339 Stores Road, \\ Vancouver BC-V6T 1Z4, Canada \\ b TERRA Teaching and Research Centre, Gembloux Agro-Bio Tech, University of Liege, 5030 Gembloux, Belgium \\ ${ }^{\mathrm{c}}$ Earth and Life Institute - Environmental Sciences, Université Catholique de Louvain, Croix du Sud 2/10, B-1348 Louvain-la-Neuve, Belgium \\ ${ }^{\mathrm{d}}$ Department of Geology (WE13), Ghent University, Krijgslaan 281/S8, B-9000 Gent, Belgium
}

\section{A R T I C L E I N F O}

Editor: Jérôme Gaillardet

Keywords:

Soil formation

Clay minerals

Si isotopes

Inheritance

Neoformation

Weathering solution

\begin{abstract}
A B S T R A C T
Soil processes strongly govern silicon (Si) mobility in terrestrial environments and its relation to other global biogeochemical cycles. The nature of inherited soil clay minerals can be highly diverse given the variability of their weathering environment. The influence of Si isotope fractionation factor in the initial geochemical conditions of clay precipitation can therefore be still expressed in inherited clay minerals in their new environment. We studied top- and subsoil of an Ethiopian Vertic Planosol derived from parent materials of similar sources of volcanism. The selected Planosol has an abrupt textural change at a depth of $\sim 40 \mathrm{~cm}$ separating a bleached, silty $(25 \pm 1.8 \%$ clay) ash-derived soil horizon with a crumby structure from a heavy clayey (68 $\pm 3.4 \%$ clay) lacustrine-derived vertic soil horizon. The mineralogical assemblage of the clay fraction in top- and subsoil is characterized by similar proportions of 1:1 (kaolinite) and 2:1 (illite and smectite) layer-type clay minerals. This specific soil profile provides a unique opportunity to elucidate the influence of clay formation processes (inheritance versus neoformation) on the Si isotope signature of pedogenic clay minerals. Minerals of the clay fraction in the clayey vertic horizon are significantly enriched in light $\mathrm{Si}$ isotope $\left(\delta^{30} \mathrm{Si}=-1.41 \pm 0.02 \%\right.$ ) compared to the bleached, silty horizon $\left(\delta^{30} \mathrm{Si}=-0.69 \pm 0.03 \%\right.$ o). These results are corroborated by the preferential enrichment in $\mathrm{Ge}$, relative to $\mathrm{Si}$, in the clay fraction of the clayey subsoil compared to the silty topsoil $\left(\mathrm{Ge} / \mathrm{Si}=6.3 \pm 0.14\right.$ and $4.0 \pm 0.10 \mu \mathrm{mol} \mathrm{mol}^{-1}$, respectively). Our results demonstrate that geochemical conditions in lacustrine environment favor kinetically-driven $\mathrm{Si}$ isotope fractionation factor leading to lower Si isotope ratios in 2:1 clay minerals inherited in the new soil profile environment. The inherited soil textural conditions in the soil profile also contribute to on-going processes that result in larger Si isotope differences between the soil solution $\left(\mathrm{CaCl}_{2}\right.$ extractable) and clay minerals. This implies that $\mathrm{Si}$ isotope signatures of clay minerals in the studied soil profile are influenced by a combination of inheritance processes in lacustrine environment and on-going neoformation processes in the soil profile. This finding has important implications for environmental studies using geochemical and $\mathrm{Si}$ stable isotope tracers to better understand current soil processes, to model elemental cycling in soil-plant systems and to quantify land-ocean element mass-balances.
\end{abstract}

\section{Introduction}

Soil biogeochemical processes control stocks and fluxes of elements in terrestrial ecosystems and need therefore to be understood for (i) optimizing cycling of nutrients in ecosystems affected by anthropogenic activities, and (ii) assessing the interconnections between biogeochemical cycling of elements in terrestrial ecosystems. Despite important progress made in modeling and its cross-validation by empirical tests (Urey, 1947; Bouchez et al., 2013), the vast number and complexity of environmental parameters controlling soil-forming processes make their understanding difficult, especially for their impact on the cycling of elements. Soil physico-chemical and mineralogical characterizations, together with geochemical and isotopic analyses help to better assess the origin of processes that govern the formation of organic and inorganic phases in soils and its resulting effects on biogeochemical balance of elements (Chadwick and Chorover, 2001). In this

\footnotetext{
*Corresponding author at: TERRA Teaching and Research Centre, Water-Soil-Plant Exchanges, Gembloux Agro-Bio Tech, University of Liege (ULiège), 5030 Gembloux, Belgium.

E-mail address: jtcornelis@uliege.be (J.-T. Cornelis).
} 
regard, the extent of stable isotope fractionation between dissolved and solid phases ( $\mathrm{Si}, \mathrm{Fe}, \mathrm{Mg}, \mathrm{Li}$ ) occurring in natural soil environments is regarded as a promising proxy to trace element pathways in terrestrial environments (Poitrasson et al., 2008; Reynolds, 2011; Pogge von Strandmann et al., 2012; Oelze et al., 2014; Opfergelt et al., 2017a). The relative enrichment in $\mathrm{Ge}$ (relative to $\mathrm{Si}$ ) and light $\mathrm{Si}$ isotope $\left({ }^{28} \mathrm{Si}\right.$ relative to ${ }^{30} \mathrm{Si}$ ) of secondary clay minerals allows to trace pedogenic processes through the soil profile and their resulting influence on biocycling of $\mathrm{Si}$ in terrestrial ecosystems and $\mathrm{Si}$ transfer from land to ocean (Ziegler et al., 2005; Cornelis et al., 2011; Opfergelt and Delmelle, 2012; Vandevenne et al., 2015; Frings et al., 2016; Opfergelt et al., 2017b).

When used in combination with $\mathrm{Ge} / \mathrm{Si}$ elemental ratio, the stable $\mathrm{Si}$ isotope ratio provides a very powerful geochemical tracer of Si pathways in soil-plant systems (Opfergelt et al., 2010; Cornelis et al., 2010). The precipitation of secondary clay minerals, which preferentially incorporate light $\mathrm{Si}$ isotopes relative to soil solution (low $\delta^{30} \mathrm{Si}$ value) (Ziegler et al., 2005; Georg et al., 2007; Opfergelt et al., 2010), depletes the soil solution in light $\mathrm{Si}$ isotope (high $\delta^{30} \mathrm{Si}$ value) compared to the soil parent material (Cardinal et al., 2010; Cornelis et al., 2010). Silicon isotope analyses need therefore to be combined with those of $\mathrm{Ge} / \mathrm{Si}$ ratios (Froelich and Andreae, 1981) as biogenic Si precipitates in plants (phytoliths) and incorporates stable Si isotopes with a large range of isotopic fractionation (Reynolds, 2011; Cornelis et al., 2011; Opfergelt and Delmelle, 2012; Frings et al., 2016). Precipitation of secondary clay minerals preferentially concentrates $\mathrm{Ge}$ (high $\mathrm{Ge} / \mathrm{Si}$ ) compared to phytoliths which do not incorporate Ge (low Ge/Si) (Kurtz et al., 2002; Derry et al., 2005; Lugolobi et al., 2010; Opfergelt et al., 2010). The Si stable isotope fractionation in soils is controlled by rock weathering/ soil formation processes ( $\mathrm{Si}$ precipitation/adsorption), resulting in a specific Si isotope signature of soils. Soil desilication, increasing with the degree of soil weathering ( $\mathrm{Si}$ loss by leaching), affects $\mathrm{Si}$ isotope signatures of clay minerals (Basile-Doelsch et al., 2005; Ziegler et al., 2005; Opfergelt et al., 2011, 2012; Steinhoefel et al., 2011; Cornelis et al., 2014a; Ameijeiras-Mariño et al., 2017). The soil desilication implies formation of 1:1 clay minerals (kaolinite-type) enriched in light $\mathrm{Si}$ isotope (lower $\delta^{30} \mathrm{Si}$ value: $-2.2 \%$ ), while $2: 1$ minerals are relatively less enriched in light $\mathrm{Si}$ isotope (higher $\delta^{30} \mathrm{Si}$ value: -0.16 to $-0.52 \%$ ) (e.g., Ziegler et al., 2005; Georg et al., 2009; Opfergelt et al., 2010). In soil weathering sequence characterized by increasing annual rainfall, clay-sized minerals have lower $\mathrm{Si}$ isotope ratios in high precipitation areas ( $\mathrm{Si}$ depletion) relative to the clay-sized minerals in low precipitation areas (Bern et al., 2010; Opfergelt et al., 2012). This highlights the importance to better understand soil-forming processes controlling $\mathrm{Si}$ isotope fractionation in natural environments. The residence time of the soil weathering solution largely depends on topographic situation, soil texture, structure, porosity and resulting permeability conditions (Lasaga, 1984; Berner, 1978; Maher, 2010). This soil property has never been taken into account when studying $\mathrm{Si}$ isotope fractionation during clay mineral formation in natural soil environments, while geochemical equilibria in solid-water interfaces are strongly controlled by the chemistry and residence time of the soil solution (Sverdrup, 1996). It is therefore especially important to study the influence of contrasting geochemical conditions on $\mathrm{Si}$ isotope fractionation during the formation of pedogenic clay minerals given that solidwater silicon isotope fractionation is essentially kinetically driven as a function of the precipitation rate of Si solid phases (Geilert et al., 2015), as well temperature and $\mathrm{pH}$ conditions (Stamm et al., 2019). This system-dependent feature is mainly controlled by original $\mathrm{Si}$ concentration in solution (Oelze et al., 2014), concentration of $\mathrm{Fe}$ and $\mathrm{Al}$ hydroxide precursors (Oelze et al., 2015), and temperature and $\mathrm{pH}$ of the solid-water interface (Geilert et al., 2014; Stamm et al., 2019) during the kinetically-dominated first step of precipitation (Roerdink et al., 2015). To understand the role of initial geochemical conditions on $\mathrm{Si}$ stable isotope fractionation, we analyzed $\mathrm{Si}$ isotope and $\mathrm{Ge} / \mathrm{Si}$ ratios in soil solution, bulk soil, clay and silt fractions of a unique soil profile, an Ethiopian Vertic Planosol, characterized by the presence of a bleached, silty ash-derived soil horizon (with 25,71 , and $4 \%$ clay, silt and sand, respectively) that abruptly overlays a heavy clayey lacustrine-derived vertic horizon (with 68, 26 and 6\% clay, silt and sand, respectively). Both horizons formed from similar parent material but at different geological time and under different geochemical conditions (ash-layer deposit for the silty horizon and lacustrine deposit for the vertic horizon). We relate the $\mathrm{Si}$ isotope composition and $\mathrm{Ge} / \mathrm{Si}$ ratios of clay-sized minerals to the clay mineralogy of the two soil horizons as quantified by Dumon et al. (2014). The selected study site represents an almost perfect opportunity to assess the influence of past and current geochemical conditions on $\mathrm{Si}$ isotope signature of pedogenic clay minerals. The textural and permeability differences between the two environments (ash-derived and lacustrine-derived soil horizons) imply contrasting residence time of weathering solution that can affect $\mathrm{Si}$ isotope fractionation factor during formation of pedogenic clay minerals. The studied site allow to compare $\mathrm{Si}$ isotope signature of $1: 1$ and 2:1 clay minerals formed in contrasting geochemical conditions (Cornelis et al., 2014a), but originated from parent material of similar sources of volcanism (Van Ranst et al., 2011; Dumon et al., 2014).

\section{Materials and methods}

\subsection{Study site}

The Gilgel-Gibe catchment in south-western Ethiopia covers an area of about $5500 \mathrm{~km}^{2}$ and is located near Jimma in the Kefa zone about $260 \mathrm{~km}$ of Addis Ababa (latitude $7^{\circ} 22^{\prime} 72^{\prime \prime}-7^{\circ} 34^{\prime} 84^{\prime} \mathrm{N}$; longitude $37^{\circ}$ $21^{\prime} 05^{\prime \prime}-37^{\circ} 28^{\prime} 80^{\prime \prime}$ E). The geological complex basement was uplifted during the Upper Eocene as part of the Arabo-Ethiopian swell, which gave rise to the East-African rift system (Tadesse et al., 2003). The bedrock is characterized by rhyolite cross-cut by andesite and trachyte, columnar basaltic lavas (hawaiite) with tuff and lacustrine intercalations. The study area is mountainous (1096 to $3259 \mathrm{ma.s.1}$.) and characterized by steeply incising, $\mathrm{V}$-shaped river valleys in the catchment flanks and a less pronounced stepped landscape of consecutive terraces at the centre of the catchment close to the Omo-River basin. The climate of the Gilgel Gibe area is sub-humid. Rain mostly falls between May and September. The mean annual rainfall in the catchment increases from $1300 \mathrm{~mm}$ in the lower valley areas to $2000 \mathrm{~mm}$ in the highest regions. Temperature is fairly constant throughout the year, with the mean minimum, maximum and average temperatures at $1800 \mathrm{~mm}$ altitude (Jimma station) being $11^{\circ} \mathrm{C}, 25^{\circ} \mathrm{C}$ and $17^{\circ} \mathrm{C}$, respectively. Most land is under cultivation (63.4\%) and the remaining woodland $(8.8 \%)$ is steadily being invaded by cultures. The main crop grown in the sampling area is teff (Eragrostis abyssinica (Jacq.)). The major reference soil groups in the catchment are Nitisols, Acrisols, Ferralsols, Vertisols and Planosols (Van Ranst et al., 2011). The soil selected for this study is a Vertic Planosol (IUSS Working Group WRB, 2015) located at the Bore-Waro test site in the middle of the lower terrace at some $200 \mathrm{~m}$ distance from the Gibe river, about $30 \mathrm{~m}$ above its present alluvial plain (Fig. 1). This typical Ethiopian Vertic Planosol presents a well rooted Ap horizon of $8-10 \mathrm{~cm}$ thick above a bleached dark grey (10YR 4-5/1, moist) to light grey (10YR $7 / 2$, dry) silty ( $25 \pm 1.8 \%$ clay) $\mathrm{E}$ horizon with a crumbly structure that at about a depth of $40 \mathrm{~cm}$ abruptly overlays a black (10YR 2/1, moist and dry) heavy clayey ( $68 \pm 3.4 \%$ clay) vertic $(\mathrm{Bi})$ horizon (Van Ranst et al., 2011). The soilscape at the study area is mainly used for grazing. The vertic Bi horizon is believed to be a lacustrine deposit, resulting from the weathering of the volcanic rocks making up the catchment. The bleached $\mathrm{E}$ horizon is a weathered ash layer deposited on top of this older sediment.

\subsection{Soil sample collection and processing}

Soil samples were collected at the following systematic depths $(\mathrm{cm})$, 


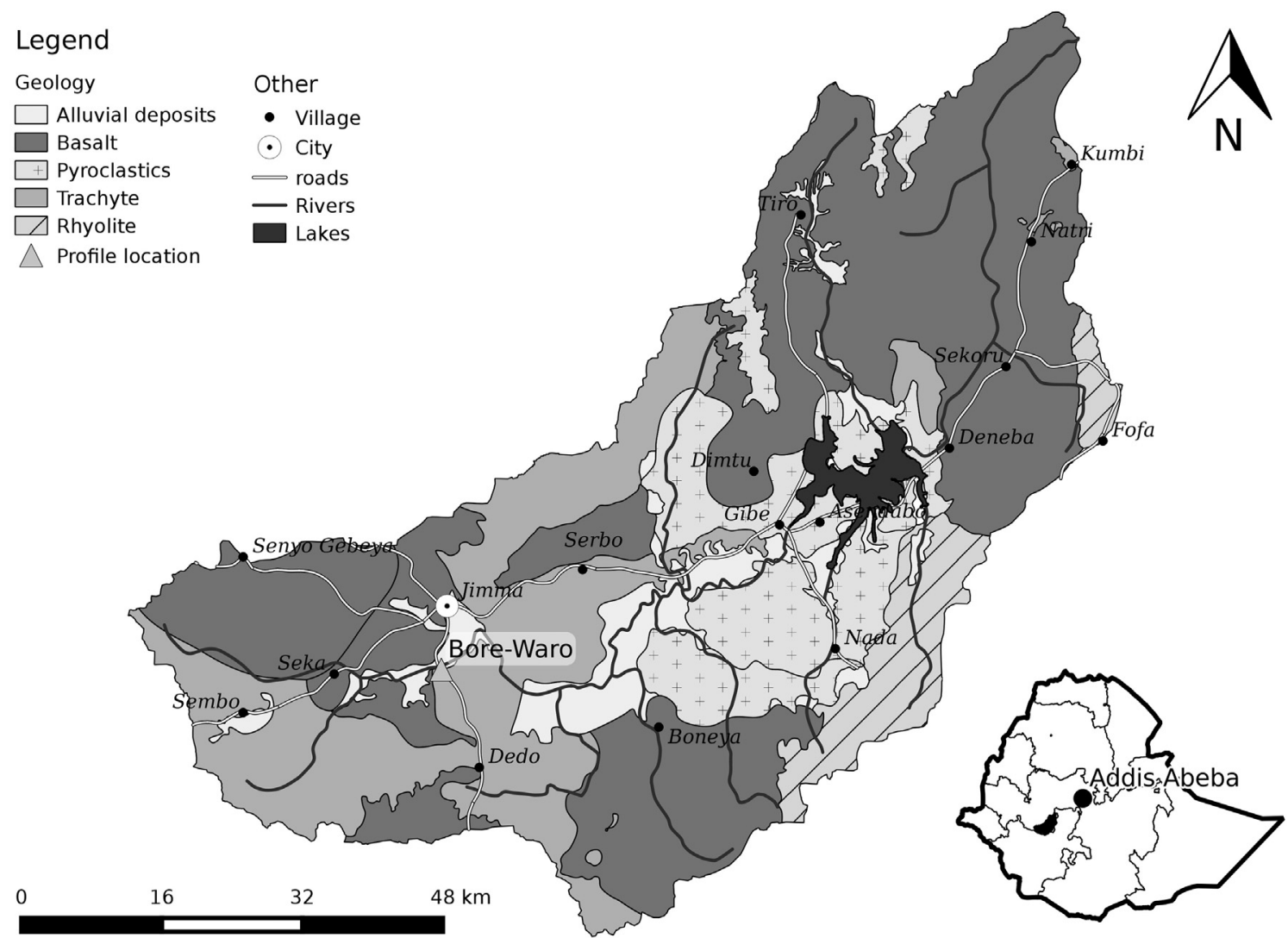

Fig. 1. Localization of the studied site on the geological map: the Bore-Waro profile (grey triangle) within the Gilgel-Gibe catchment (located in black in the inset) in Ethiopia.

with special attention to sampling at the transition between bleached and vertic horizons: 5-10 (Ap/E); 10-15; 15-20; 20-25; 25-30; 30-35 (E); 35-40 (Ecg); 40-45; 45-50; 50-55 and 70-75 (Bi). For the geochemical and isotopic analyses, the soil samples were gathered for the following horizons: Ap/E (surface horizon), E (bleached horizon) and Bi (vertic horizon). Composite samples of the major grass species were taken above and adjacent to the soil sampling area.

The particle size distribution $(<2 \mu \mathrm{m}, 2-63 \mu \mathrm{m}$ and $63-2000 \mu \mathrm{m})$ and main physico-chemical properties of air-dried fine earth $(<2 \mathrm{~mm})$ are reported in Table 1 . The sand fraction was separated from fine earth by ultrasonic dispersion and wet sieving. The clay fraction was separated from the silt fraction by dispersion with a solution of $\mathrm{Na}_{2} \mathrm{CO}_{3}$ at $\mathrm{pH}$ 9-9.5. After separation the clay is flocculated again at $\mathrm{pH} \pm 6$ with a solution of $\mathrm{HCl}$ and $\mathrm{NaCl}$ (Christensen, 1992). The recovered clay was thoroughly washed with alcohol to remove excess chloride, centrifuged at $3500 \mathrm{rpm}$ after each step. The soil fractions were used for a detailed mineralogical characterization.

Oriented samples of $\mathrm{Ca}^{2+}$-saturated clay fractions were prepared by transferring a suspension on glass slides. For each air-dried slide an Xray diffraction (XRD) pattern was recorded before and after glycolation. These patterns have been designed using structural models optimized for each clay species present. More details on sample preparation, measuring conditions, interpretation and modeling can be found in Dumon et al. (2014). The silt fraction was micronized to a particle size $<10 \mu \mathrm{m}$ using a McCrone micronizing mill, ethanol as grinding fluid and after addition of $5 \% \mathrm{ZnO}$ as internal standard. The obtained slurries were then spray-dried (Kleeberg et al., 2008) after which an XRD pattern was recorded. The XRD patterns were quantified using the

Table 1

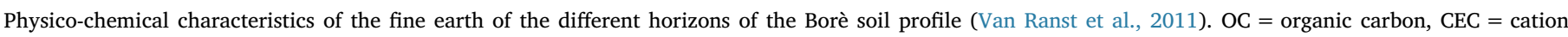
exchange capacity, base saturation $=$ ratio of the $[$ sum of exchangeable $\mathrm{Ca}+\mathrm{Mg}+\mathrm{K}+\mathrm{Na}] / \mathrm{CEC}$.

\begin{tabular}{|c|c|c|c|c|c|c|c|c|c|c|c|c|}
\hline \multirow[t]{2}{*}{ Horizon } & \multirow[t]{2}{*}{$\begin{array}{l}\text { Depth } \\
(\mathrm{cm})\end{array}$} & \multirow[t]{2}{*}{ Clay } & Silt & \multicolumn{2}{|l|}{ Sand } & \multirow[t]{2}{*}{$\mathrm{pH}_{\mathrm{H} 2 \mathrm{O}}$} & \multicolumn{5}{|c|}{$\begin{array}{l}\text { Exchangeable complex } \\
\left(\mathrm{cmol}_{\mathrm{c}} \mathrm{kg}^{-1}\right)\end{array}$} & \multirow{2}{*}{$\begin{array}{l}\text { Base saturation } \\
(\%)\end{array}$} \\
\hline & & & $2-63 \mu \mathrm{m}$ & $63 \mu \mathrm{m}-2 \mathrm{~mm}$ & $\mathrm{OC}_{\text {tot }}$ & & CEC & $\mathrm{Ca}$ & $\mathrm{Mg}$ & K & $\mathrm{Na}$ & \\
\hline $\mathrm{Ap} / \mathrm{E}$ & $5-10$ & 27 & 69 & 4 & 3.08 & 5.2 & 20.7 & 6.0 & 1.2 & 0.7 & 0.2 & 38 \\
\hline $\mathrm{E}$ & $10-15$ & 27 & 69 & 4 & 1.90 & 5.3 & 16.1 & 5.0 & 0.9 & 0.2 & 0.2 & 40 \\
\hline E & $15-20$ & 26 & 70 & 4 & 1.35 & 5.2 & 13.0 & 4.0 & 0.9 & 0.1 & 0.2 & 38 \\
\hline E & $20-25$ & 24 & 72 & 4 & 0.82 & 5.1 & 10.0 & 3.3 & 0.7 & 0.1 & 0.2 & 43 \\
\hline $\mathrm{E}$ & $25-30$ & 23 & 73 & 4 & 0.58 & 5.3 & 8.8 & 3.4 & 0.7 & 0.1 & 0.2 & 51 \\
\hline E & $30-35$ & 23 & 73 & 4 & 0.51 & 5.6 & 8.8 & 4.3 & 0.8 & 0.1 & 0.3 & 62 \\
\hline Ecg & $35-40$ & 25 & 67 & 8 & 0.53 & 5.6 & 11.0 & 5.4 & 1.2 & 0.1 & 0.3 & 64 \\
\hline $\mathrm{Bi}$ & $40-45$ & 63 & 30 & 7 & 1.05 & 5.9 & 45.9 & 26.2 & 6.4 & 0.7 & 0.7 & 74 \\
\hline $\mathrm{Bi}$ & $45-50$ & 70 & 25 & 5 & 1.01 & 6.0 & 52.0 & 32.7 & 7.9 & 0.7 & 0.8 & 81 \\
\hline $\mathrm{Bi}$ & $50-55$ & 69 & 26 & 5 & 0.89 & 5.8 & 51.9 & 33.8 & 7.6 & 0.8 & 0.8 & 83 \\
\hline $\mathrm{Bi}$ & $70-75$ & 70 & 25 & 5 & 0.94 & 6.0 & 53.1 & 35.9 & 9.0 & 0.8 & 0.8 & 87 \\
\hline
\end{tabular}


BGMN Rietveld model and using Profex as the user interface (Doebelin and Kleeberg, 2015). The amorphous material was quantified using a structure file calibrated with pure amorphous material separated from the samples, as described below (Scarlett and Madsen, 2006). The samples still contained some phyllosilicates which were modelled using an ordered kaolinite (Bish and Von Dreele, 1989) and a dioctahedral turbostratic smectite (Ufer et al., 2004) structure. The XRD patterns were collected on a Bruker D8 ECO advance equipped with a $\mathrm{Cu}$ anode $\mathrm{X}$-ray tube and a position-sensitive, energy-dispersive LYNXEYE XE detector. Patterns were collected using a Bragg-Brentano $\theta-\theta$ geometry from $3^{\circ} 2 \theta$ onwards.

The pool of so-called "plant-available $\mathrm{Si}$ " (Sauer et al., 2006), i.e. silicic acid in aqueous phase, was assessed by using a $0.01 \mathrm{M} \mathrm{CaCl}_{2}$ extraction made from a $99 \%$ pure $\mathrm{CaCl}_{2}$ powder. Here, the $\mathrm{CaCl}_{2}$ extractable solution is assumed to represent soil solution. Five grams of equivalent soil dry weight was shaken with $50 \mathrm{ml}$ of $\mathrm{CaCl}_{2}$ solution for $5 \mathrm{~h}$ at $20^{\circ} \mathrm{C}$. The suspension was then centrifuged at $3000 \mathrm{rpm}$ for $10 \mathrm{~min}$ and the supernatant filtered through Wathman no. 2 paper.

For the extraction of phytoliths from grasses, i.e. phytogenic silica $(\mathrm{PhSi})$, plant samples were washed successively with de-ionized water, $\mathrm{HCl} 1 \mathrm{M}$, ethanol $70 \%$ and rinsed again with de-ionized water in order to avoid dust and aeolian contaminations (Kelly, 1990). The grass samples dried overnight at $40{ }^{\circ} \mathrm{C}$ were grinded and digested at $120^{\circ} \mathrm{C}$ in a concentrated $\mathrm{HNO}_{3}(70 \%) / \mathrm{H}_{2} \mathrm{O}_{2}(30 \%)$ mixture until the reaction ceased. The PhSi was filtered through a pre-weighed Whatman membrane $0.2 \mu \mathrm{m}$ filter and rinsed with de-ionized water.

In soil, the amorphous silica particles with a density below $2.3 \mathrm{~g} \mathrm{~cm}^{-3}$ (mainly PhSi; Cornelis et al., 2014b) were separated from the silt fraction $(2-63 \mu \mathrm{m})$ following the heavy liquid method adapted from Kelly (1990). About $40 \mathrm{~cm}^{3}$ of a zinc bromide solution $\left(\mathrm{ZnBr}_{2}\right.$, density $=2.3 \mathrm{~g} \mathrm{~cm}^{-3}$ ) was added to $0.5 \mathrm{~g}$ of silt fraction and centrifuged at $4000 \mathrm{rpm}$ for $10 \mathrm{~min}$ as described in Cornelis et al. (2010). The supernatant containing the floating material was carefully removed with a pipette and filtered through a pre-weighed $2.0 \mu \mathrm{m}$ Teflon filter (PTFE), then rinsed with $\mathrm{HCl} 1 \mathrm{M}$ and de-ionized water. The operation was repeated until negligible material is obtained (Herbauts et al., 1994).

The silt and sand fractions were examined using a petrographic microscope in plane polarized light (PPL) and crossed polarizers (XPL) after mounting the samples on a glass slide using glycerol. The magnetically less- and more-susceptible minerals of the coarser sand fraction $(100-2000 \mu \mathrm{m})$ were separated by means of a magneto-separator using a current of 0.5 A (Cornelis et al., 2014b).

\subsection{Analytical techniques for $\mathrm{Ge} / \mathrm{Si}$ and Si isotope measurements}

\subsubsection{Reagents and standards}

All dissolutions and chemical separations were carried out in Class 100 laminar flow hoods in the Class 1000 clean labs and the mass spectrometric analyses were performed in Class 10,000 labs at the Pacific Centre for Isotopic and Geochemical Research (PCIGR) at the University of British Columbia. All reagents used were purified in-house by sub-boiling distillation in Teflon ${ }^{\circledR}$ Savillex bottles. All dilutions, rinses and cleanings were made using doubly de-ionized water (DDW) at $18 \Omega \mathrm{cm}^{-1}$. The bottles, tubes and Savillex ${ }^{\circledast}$ used for chemistry and MC-ICP-MS analyses were cleaned prior to each use in hot $\left(70^{\circ} \mathrm{C}\right)$ alkaline cleanser (extran ${ }^{\circledast} 300$ ) for 2 days, followed by 1 day in hot concentrated reagent grade $\mathrm{HCl}, 1$ day in hot concentrated $\mathrm{HNO}_{3}$ and then by final rinsing five times in cold DDW. Savillex ${ }^{\circledast}$ PFA vials used to collect purified Si samples were cleaned in an additional step with $\mathrm{HF}$ $10 \% / \mathrm{HNO}_{3} 50 \% v / \mathrm{v}$. Accuracy and reproducibility were checked for (i) $\delta^{30} \mathrm{Si}$ over a period of 7 months on the silica standard NBS-28, used as the international 'zero-point' reference material, and (ii) on a daily basis by analyses of secondary reference material diatomite (prepared and distributed by M. Brzezinski, University of California Santa Barbara) and USGS rock standard BHVO-2, and (2) for Ge on USGS rock standard AGV-1 and BCR-1.

\subsubsection{Sample digestion}

Silicon isotope composition and $\mathrm{Ge} / \mathrm{Si}$ ratios were measured on bulk soil, silt and clay fractions, phytoliths ( $\mathrm{PhSi}$ ), amorphous silica from silt fraction ( $\mathrm{ASi}$ ) and $\mathrm{CaCl}_{2}$-extractable soil solutions from the bleached (E) and vertic $(\mathrm{Bi})$ horizons.

An alkaline digestion with $99.99 \%$ pure $\mathrm{NaOH}$ was used to transform soil and phytolith samples into an aqueous HF-free solution. Solid soil samples were ground using a Si-free alumina (99.5\%) mortar and pestle. Between 5 and $10 \mathrm{mg}$ of the powdered samples were weighted out into Ag crucibles (made in-house from $99.9985 \%$ pure Ag sheet and rod) in which one pellet of $\mathrm{NaOH}$ flux $(\sim 120 \mathrm{mg})$ was added. The Ag crucibles were covered with an $\mathrm{Ag}$ sheet and the fusion was carried out in a muffle furnace for $10 \mathrm{~min}$ at $720^{\circ} \mathrm{C}$. After slight cooling, the crucibles and the cover plates were transferred into Savillex ${ }^{\circledR}$ beakers containing $15 \mathrm{ml}$ DDW, in which the fusion cake dissolved. The solutions were briefly agitated ultrasonically before being transferred into pre-cleaned HDPE bottles using PTFE funnels. The crucibles and Savillex ${ }^{\circledast}$ beakers were rinsed three times to ensure the complete transfer of the fusion cake. Solutions were then acidified by adding $1.2 \mathrm{ml}$ of concentrated $\mathrm{HNO}_{3}(14 \mathrm{~N}$ ), for $120 \mathrm{mg} \mathrm{NaOH}$ flux (Georg et al., 2006). The recovery of $\mathrm{Si}$ for the fusion procedure of standard (NBS-28) and reference materials (BHVO-2 and diatomite) was $99.0 \pm 1.8 \%$ ( $1 \mathrm{SD}, n=9$ ), which is in good agreement with the $99.4 \pm 2.6 \%$ recovery of Georg et al. (2006).

\subsubsection{Si measurement by ICP-OES}

$\mathrm{Si}$ contents were analyzed directly in the solution from $\mathrm{NaOH}$ fusion and $\mathrm{CaCl}_{2}$ extraction by ICP-OES (Varian 725-ES) with europium as internal standard. The accuracy was checked on reference BHVO-2 material. Our result on BHVO-2 (23.12 $\pm 0.69 \%, 2 \mathrm{SD}, n=6)$ was in good agreement with the recommended value $(23.3 \pm 0.60 \%)$ provided by USGS (Wilson, 1997). Precision for 6 replicates of BHVO-2 on three different sessions of analysis was 1.5\% RSD. Detection limit, determined by measuring the standard deviation on 4 total procedural blanks, was $100 \mathrm{ppb}$.

\subsubsection{Silicon separation chemistry}

The cation exchange chromatography procedure used to isolate $\mathrm{Si}$ follows the method of Georg et al. (2006). Three duplicates of fusion of NBS-28, BHVO-2 and diatomite were used to check for Si yields during the chemical purification and for accuracy of $\mathrm{Si}$ isotopic compositions. The soil solution samples extracted with $\mathrm{CaCl}_{2}$ were purified, as dissolved samples from fusion, through a cation exchange resin (BioRad AG50W-X12) filled to a $1.8 \mathrm{ml}$ resin bed in BioRad columns (Georg et al., 2006). Before loading and purifying samples, the resin was cleaned in the column with $3 \mathrm{~N} \mathrm{HCl}, 6 \mathrm{~N} \mathrm{HCl}, 7 \mathrm{~N} \mathrm{HNO}_{3}, 10 \mathrm{~N} \mathrm{HCl}, 6 \mathrm{~N}$ $\mathrm{HCl}, 3 \mathrm{~N} \mathrm{HCl}$ and then rinsed three times with DDW until a pH of 5.5 is reached. The Si eluate were collected in Savillex ${ }^{\circledR}$ PFA vials. The Si concentrations in the total procedural blanks from columns (i.e., 3 blanks from $\mathrm{NaOH}$-fusion loaded in three different purification columns) were negligible (below the detection limit of ICP-OES, $100 \mathrm{ppb}$ ). For a Si loading between 2 and $200 \mu \mathrm{g}$ in the eluate solution, the $\mathrm{Si}$ recovery was $100 \%$ after three rinses with $1 \mathrm{ml}$ DDW. Before loading, the samples were diluted to $20 \mathrm{ppm}$, by applying exactly the same elution volumes for all samples. The elute sample volume was $2 \mathrm{ml}$, and then diluted to $5 \mathrm{ml}$ by adding three times a DDW elution volume of $1 \mathrm{ml}$. The final Si concentration $(8 \mathrm{ppm})$ in the purified solution was checked by ICP-OES, as well as $\mathrm{Na}$ and $\mathrm{Ca}$ concentrations (that were below the detection limit) to check the purity of the final solution. The amount of Si used $(40 \mu \mathrm{g})$ is approximately ten times higher than the $3.6 \mu \mathrm{g}$ load used for $\mathrm{Si}$ isotopes analyses using the high resolution capacity of the Nu Plasma 1700 (ETH Zürich) (Georg et al., 2006), but seven times lower than the $300 \mu \mathrm{g}$ load used for the anion exchange chromatography (Engström et al., 2006). The Si recovery of the column 
purification, monitored using standard and reference materials in order to avoid isotopic fractionation associated with chromatographic separation, is $100.4 \pm 2.9$ ( $\pm 1 \mathrm{SD}, n=31$ ), which is close to the value of Georg et al. (2006): $100.1 \pm 1.6 \%$.

\subsubsection{Si isotope measurement by MC-ICP-MS}

Silicon isotope compositions were measured on a $\mathrm{Nu}$ Plasma $\mathrm{Cu}$ 021; Nu Instruments Ltd., UK) multi-collector inductively coupled plasma mass spectrometer (MC-ICP-MS) in dry plasma mode (cones of type B; Nu instruments) using a Cetac Aridus II desolvating device and an external $\mathrm{Mg}$ doping to correct mass bias in a $\mathrm{HNO}_{3}$ matrix (Cardinal et al., 2003). The source slit was set to pseudo-high resolution (medium) mode and the collector slit was adjusted for each session in order to resolve polyatomic interferences of ${ }^{14} \mathrm{~N}^{16} \mathrm{O}$ on the ${ }^{30} \mathrm{Si}$ ion beam and of ${ }^{14} \mathrm{~N}_{2}$ on the ${ }^{28} \mathrm{Si}$ ion beam (Abraham et al., 2008). After a washing of $3 \mathrm{~min}$ in $\mathrm{HNO}_{3} 3 \%$ and $2 \mathrm{~min}$ in $\mathrm{HNO}_{3} 0.2 \%$, the instrumental blanks are $<15 \mathrm{mv}$ using a PFA nebulizer with an uptake rate of $50-80 \mu \mathrm{l} / \mathrm{min}$. One $\delta^{30} \mathrm{Si}$-value is comprised of 25 cycles with $8 \mathrm{~s} \mathrm{in-}$ tegration time for each cycle with a 20 s on-peak zero measurement before each analysis. The instrumental mass bias was corrected according to the standard-sample bracketing protocol, i.e. one sample measurement normalized to the average of two adjacent NBS-28 standard measurements. Silicon isotopic compositions are expressed as deviation of ${ }^{30} \mathrm{Si} /{ }^{28} \mathrm{Si}$ relative to the NBS-28 reference standard using the delta $(\delta)$ per mil (\%) notation as follows:

$\delta^{30} S i=\left[\frac{\left(\frac{{ }^{30} S i}{{ }^{28} S i}\right)_{\text {sample }}}{\left(\frac{{ }^{30} S i}{{ }^{28} S i}\right)_{N B S 28}}-1\right] * 1000$

Each sample was measured three times during at least two different analytical sessions. Silicon isotopic $\delta^{30}$ Si-values are reported as the mean of replicate isotopic analyses $(n=3) \pm 2$ standard deviations (SD). The accuracy and reproducibility of the measurements were controlled by the measurement of (i) eight $\delta^{30}$ Si-values of NBS-28 over $2 \mathrm{~h}$ before any analysis, and (ii) secondary reference materials (diatomite and BHVO-2) at the beginning and at the end of each sample series. The instrument sensitivity varies between 2 and $3.5 \mathrm{~V} / \mathrm{ppm} \mathrm{Si}$ at $0.1 \mathrm{ml} / \mathrm{min}$ uptake.

The reproducibility was checked over a period of 7 months (data were acquired during 4 sessions) on standard NBS-28 material: $0.01 \pm 0.19 \%$ o (2SD, $n=45$ ). This reproducibility also includes the repeatability of the protocol of fusion-dissolution-chromatography since the NBS-28 standards were processed through the chemical purification from different fusion procedures before each session. Accuracy and reproducibility on $\delta^{30}$ were also checked on reference materials during each session ensuring values similar to published values (Reynolds et al., 2007; Abraham et al., 2008; Georg et al., 2009; Opfergelt et al., 2011): $1.25 \pm 0.15 \%$ (2SD, $n=10)$ for diatomite and $-0.29 \pm 0.21 \%$ (2SD, $n=5$ ) for BHVO-2. We also checked the control of mass bias on $\delta^{30} \mathrm{Si}$ and $\delta^{29} \mathrm{Si}$ by ensuring that the measured $\delta^{30} \mathrm{Si}$ values had an atomic mass unit difference between the $\delta^{30}$ and $\delta^{29}<0.10$.

\subsubsection{Ge chemistry and measurement by HR-ICP-MS}

For Ge concentration measurements, the alkaline $\mathrm{NaOH}$ fusion was also performed on USGS rock standards AGV-1 and BCR-1. For soil and plant samples and USGS standards, aliquots of $5 \mathrm{~g}$ of the solution from the $\mathrm{NaOH}$ fusion were transferred into Savillex ${ }^{\circledR}$, then dried at $120^{\circ} \mathrm{C}$ overnight and subsequently re-dissolved in $3 \mathrm{ml} 1 \% \mathrm{v} / \mathrm{v} \mathrm{HNO}_{3}$ spiked with $1 \mathrm{ng} \mathrm{g}^{-1} \mathrm{In}$. The Savillex ${ }^{\circledast}$ beakers were capped and again placed on a hotplate at $120^{\circ} \mathrm{C}$ for $10 \mathrm{~min}$. The solutions were briefly ultrasonicated before their transfer into pre-cleaned HDPE bottles. The Savillex ${ }^{\circledast}$ beakers were rinsed and added to the HDPE bottles. The solutions were gravimetrically diluted 2 times to a weight of $10 \mathrm{~g}$ and $\mathrm{Ge}$ concentrations were determined by measurement of ${ }^{74} \mathrm{Ge}$ isotope directly on the HR-ICP-MS (Finnigan Element 2) in medium resolution.

Indium was used as the internal standard to correct for both instrumental (i.e., mass) drift, and sensitivity drift potentially arising from the sample matrix (Pretorius et al., 2006; Carpentier et al., 2013; Schudel et al., 2015). A total procedural blank was included with each batch of seven samples analyzed. The detection limit for Ge, checked by measuring the 2 standard deviations (2SD) on 6 procedural blanks of the $\mathrm{NaOH}$ fusion, was $1.6 \mathrm{ppb}$. Accuracy and reproducibility were also checked on reference materials during each session ensuring values nearly identical to the ones reported using isotope-dilution hydridegeneration ICP-MS technique developed by Mortlock and Froelich (1996): BCR-1 = $1.52 \pm 0.2$ ppm (Kurtz et al., 2002), $1.59 \pm 0.2 \mathrm{ppm}$ (Scribner et al., 2006) and AGV-1 = $1.25 \pm 0.1 \mathrm{ppm}$ (value downloaded from GeoRem; Jochum et al., 2005). Our analysis of Ge in BCR-1 (1.64 $\pm 0.18 \mathrm{ppm}, 2 \mathrm{SD}, n=7)$ and in AGV-1 (1.13 $\pm 0.17 \mathrm{ppm}, 2 \mathrm{SD}$, $n=8$ ) agrees within error to the published values. Reproducibility for 7 replicates of BIR-1 on two sessions was $6 \%$ relative standard deviation (RSD). Each sample was measured two times.

\section{Results}

\subsection{Soil physico-chemical characteristics}

The soil characteristics of the studied Vertic Planosol thoroughly described in Van Ranst et al. (2011) and Cornelis et al. (2014b) are presented in the Table 1 . The abrupt textural change between bleached, silty (around 70\% silt) E and the black, heavy clayey (around 70\% clay) Bi horizons is also characterized by an increase in organic carbon content from 0.5 to $1.0 \%$ and especially an increase of the cation exchange capacity (CEC), from 11 to $46 \mathrm{cmol}(+) / \mathrm{kg}$. Both of the horizons have a very small sand content (about $5 \%$ ). The upper bleached soil horizon has much higher total $\mathrm{SiO}_{2}(>72 \%), \mathrm{Na}_{2} \mathrm{O}(1.1-1.3 \%)$ and $\mathrm{K}_{2} \mathrm{O}$ (1.8-3.7\%) contents compared to the clayey vertic subsoil (53-55\% $\mathrm{SiO}_{2}, 0.4-0.5 \% \mathrm{Na}_{2} \mathrm{O}$ and $1.1-1.4 \% \mathrm{~K}_{2} \mathrm{O}$ ), indicating the dominance of siliceous components and feldspars in the upper horizon. At the transition between the two horizons, the increase of $\mathrm{Al}_{2} \mathrm{O}_{3}, \mathrm{CaO}, \mathrm{MgO}$, and $\mathrm{H}_{2} \mathrm{O}$ (loss on ignition) contents are due to the dominance of smectitic minerals in the clay fraction of the vertic horizon (Van Ranst et al., 2011).

\subsection{Microscopic observations}

A high content of phytoliths and irregularly shaped amorphous fragments of volcanic glass was observed in the coarser (silt and sand) fractions of the bleached horizon. Given that phytoliths are also mainly silt-sized, one can assume that the magnetic susceptible amorphous fragments in the sand fraction are volcanic glass, which were not detected in the same fraction of the vertic horizon. Indeed, smaller fragments were found in the silt fraction of the vertic horizon. The microscopic analysis of the silt fraction having a density below $2.3 \mathrm{~g} \mathrm{~cm}^{-3}$ revealed a composition dominated by phytoliths showing morphologies very similar to those of the phytoliths extracted from grasses (Van Ranst et al., 2011; Cornelis et al., 2014b).

The mineralogical composition of the sand fraction $(>100 \mu \mathrm{m})$ of the bleached and vertic horizons is not significantly different. The most abundant minerals in this fraction are magnetic non-susceptible quartz (78\%) and feldspars (13\%). The magnetic susceptible fraction consists mainly of colorless fragments of volcanic glass and represents $9 \%$ of the sand fraction.

\subsection{Quantitative clay mineralogy}

The studied Vertic Planosol presents a complex clay mineralogy. The clay fraction of the bleached $\mathrm{E}$ horizon is composed of a mixture of kaolinite and illite $(>0.2 \mu \mathrm{m})$ and smectite and kaolinite/smectite 
Table 2

Absolute weight fractions of the different phyllosilicate layer-types within the bulk clay fraction and sub-fractions of the studied Planosol (based on data from Dumon et al. (2014)). The relative weight of a given mineral in each subfraction is given in parenthesis.

\begin{tabular}{|c|c|c|c|c|}
\hline Horizon & Layer types & $<0.05 \mu \mathrm{m}$ & $0.2-2 \mu \mathrm{m}$ & Bulk $<2 \mu \mathrm{m}$ \\
\hline & & $/ w t \%$ & $/ w t \%$ & $/ w t \%$ \\
\hline \multirow[t]{4}{*}{ Bleached E horizon } & Kaolinite & $\begin{array}{l}18 \\
(50 \%)\end{array}$ & $\begin{array}{l}17 \\
(30 \%)\end{array}$ & $\begin{array}{l}35 \\
(38 \%)\end{array}$ \\
\hline & Illite & $\begin{array}{l}2 \\
(5 \%)\end{array}$ & $\begin{array}{l}33 \\
(59 \%)\end{array}$ & $\begin{array}{l}35 \\
(38 \%)\end{array}$ \\
\hline & Smectite & $\begin{array}{l}16 \\
(45 \%)\end{array}$ & $\begin{array}{l}6 \\
(11 \%)\end{array}$ & $\begin{array}{l}22 \\
(24 \%)\end{array}$ \\
\hline & Total & 36 & 56 & $92^{\mathrm{a}}$ \\
\hline \multirow[t]{4}{*}{ Vertic Bi horizon } & Kaolinite & $\begin{array}{l}32 \\
(40 \%)\end{array}$ & $\begin{array}{l}2 \\
(25 \%)\end{array}$ & $\begin{array}{l}34 \\
(39 \%)\end{array}$ \\
\hline & Illite & $\begin{array}{l}3 \\
(4 \%)\end{array}$ & $\begin{array}{l}5 \\
(63 \%)\end{array}$ & $\begin{array}{l}8 \\
(9 \%)\end{array}$ \\
\hline & Smectite & $\begin{array}{l}44 \\
(55 \%)\end{array}$ & $\begin{array}{l}1 \\
(12 \%)\end{array}$ & $\begin{array}{l}45 \\
(52 \%)\end{array}$ \\
\hline & Total & 79 & 8 & $87^{\mathrm{a}}$ \\
\hline
\end{tabular}

a The material of the $0.05-0.2 \mu \mathrm{m}$ sub-fraction was not analyzed, explaining the $<100 \%$ totals.

mixed-layers $(<0.05 \mu \mathrm{m})$, while the clay fraction of the vertic Bi horizon is dominated by a large amount of fine clay composed of smectite and kaolinite/smectite mixed-layers $(<0.05 \mu \mathrm{m})$. Despite higher content of fine clay in the bulk vertic horizon, the proportion of the different clay mineral species (kaolinite, illite and smectite) between $\mathrm{E}$ and $\mathrm{Bi}$ soil horizons is nearly identical in the clay sub-fractions $(<0.05 \mu \mathrm{m}$ and 0.2-2 $\mu \mathrm{m}$; Table 2) (Dumon et al., 2014). A quantitative composition of this complex mineralogy whereby only the amount of kaolinite, illite and smectite layers present in the different phases are considered and by disregarding the layer-stacking is given in Table 2 (from Dumon et al., 2014). The data illustrates that the fine clay fraction $(<0.05 \mu \mathrm{m})$ of both horizons is composed of dominantly kaolinite and smectite layer types in roughly the same proportion, with only minor amounts of illite layer types. The coarse clay fraction $(2-0.2 \mu \mathrm{m})$ of both horizons is composed dominantly of illite layer types and to a lesser degree of kaolinite layer types. Only minor amounts of smectite layer types are present. The summation of the content of each clay mineral species of the two sub-fractions leads to the difference in mineralogy for the bulk $(<2 \mu \mathrm{m})$ clay fraction: $\mathrm{E}$ horizon more concentrated in illite and $\mathrm{Bi}$ horizon more concentrated in smectite. Based on X-ray characteristics (Dumon et al., 2014), illite is assumed not to be derived from primary rock-forming mica.

\subsection{Quantitative silt-sized mineralogy}

About $50 \%$ of the silt fraction is amorphous (volcanic glass and phytoliths), quartz makes up 22 to $30 \%$, feldspars 11 to $18 \%$ and phyllosilicates 6 to $17 \%$ (Table 3). Given the broad 001 reflections in

Table 3

Mineralogical composition (in wt $\%$ ) of the silt fraction $(2-63 \mu \mathrm{m})$ in the Borè soil profile as determined by Rietveld refinement.

\begin{tabular}{lccccc}
\hline Horizon & E horizon & E horizon & E horizon & Bi horizon & Bi horizon \\
\hline Depth (cm) & $10-15$ & $20-25$ & $30-35$ & $45-50$ & $70-75$ \\
\hline Amorphous & 55.6 & 52.6 & 49.2 & 39.4 & 41.3 \\
Quartz & 22.4 & 27.2 & 29.8 & 25.9 & 26.7 \\
Feldspars & 11.3 & 12.8 & 14.1 & 15.4 & 17.9 \\
Phyllosilicates & 10.4 & 6.7 & 6.1 & 16.7 & 12.9 \\
Anatase & $<1$ & $<1$ & $<1$ & $<1$ & $<1$ \\
Hematite & $<1$ & $<1$ & $<1$ & $<1$ & $<1$ \\
Goethite & $<1$ & $<1$ & $<1$ & 1.8 & $<1$ \\
\hline
\end{tabular}

combination with a typical turbostratic hk0 band, we can assume the phyllosilicates present to have a similar origin to those present in the clay fraction (smectite and kaolinite type layers). Most likely these phyllosilicates are in fact clay-sized, but are either coating or attached to silt-sized particles. The composition of the silt fraction in the vertic horizon is comparable, but with lower amounts of amorphous material and higher amounts of phyllosilicates.

\subsection{Ge/Si ratios in soil, plant and solutions}

The $\mathrm{Ge} / \mathrm{Si}$ ratio measured in $\mathrm{PhSi}$ extracted from grasses (phytoliths) is $0.3 \pm 0.02 \mu \mathrm{mol} \mathrm{mol}^{-1}$ (Table 4). Amorphous silica extracted from soil (phytoliths and volcanic glass) are characterized by the lowest $\mathrm{Ge} / \mathrm{Si}$ ratios, $0.08 \pm 0.01 \mu \mathrm{mol} \mathrm{mol}{ }^{-1}$ and $0.04 \pm 0.01 \mu \mathrm{mol} \mathrm{mol}^{-1}$, respectively, in $\mathrm{E}$ and $\mathrm{Bi}$ horizons. The $\mathrm{Ge} / \mathrm{Si}$ ratios of bulk soil differed between the two horizons, with a lower value for $\mathrm{E}$ horizon $\left(1.4 \pm 0.06 \mu \mathrm{mol} \mathrm{mol}^{-1}\right)$ compared to $\mathrm{Bi}$ horizon $\left(4.6 \pm 0.12 \mu \mathrm{mol} \mathrm{mol}^{-1}\right)$. The silt fractions of $\mathrm{E}$ and $\mathrm{Bi}$ horizons displayed strictly identical $\mathrm{Ge} / \mathrm{Si}$ ratios with a value of $0.8 \pm 0.02 \mu \mathrm{mol} \mathrm{mol}^{-1}$, while $\mathrm{Ge} / \mathrm{Si}$ ratios of clay fractions varied between $\mathrm{E}$ and $\mathrm{Bi}$ horizons: $4.0 \pm 0.10 \mu \mathrm{mol} \mathrm{mol}^{-1}$ and $6.3 \pm 0.14 \mu \mathrm{mol} \mathrm{mol}^{-1}$, respectively. The $\mathrm{Ge} / \mathrm{Si}$ ratios in $\mathrm{CaCl}_{2}$-extractable solutions were identical in both horizons: $0.3 \pm 0.20 \mu \mathrm{mol} \mathrm{mol}^{-1}$.

\subsection{Si isotope compositions in soil, plant and solutions}

Phytoliths extracted from plants (BSi) displayed $\delta^{30} \mathrm{Si}$ values of $0.22 \pm 0.05 \%$ o (2SD, $n=3$ ). Amorphous silica particles extracted from soil (volcanic glass and phytoliths) are characterized by the highest $\delta^{30} \mathrm{Si}$ values: $1.56 \pm 0.10 \%$ in $\mathrm{E}$ horizon and $1.87 \pm 0.17 \%$ in $\mathrm{Bi}$ horizon. The $\delta^{30} \mathrm{Si}$ values of bulk soil differed between the two soil horizons: lower isotope ratios in Bi horizon $(-0.57 \pm 0.32 \%$ ) compared to E horizon $\left(0.40 \pm 0.18 \%\right.$ ). This enrichment in light ${ }^{28} \mathrm{Si}$ is also observed in the respective clay fractions: lower isotope ratios in $\mathrm{Bi}$ horizon $(-1.41 \pm 0.02 \%) \quad$ compared to $\mathrm{E}$ horizon $(-0.69 \pm 0.02 \%)$. The Si isotopic signature of silt fractions is quite similar: $0.48 \pm 0.29 \%$ in $\mathrm{E}$ horizon and $0.37 \pm 0.32 \%$ in Bi horizon. The $\mathrm{CaCl}_{2}$-extractable solutions are characterized by different $\delta^{30} \mathrm{Si}$ values: Bi horizon depleted in light ${ }^{28} \mathrm{Si}(1.58 \pm 0.16 \%$ ) compared to E horizon $(0.12 \pm 0.21 \%)$.

\section{Discussion}

\subsection{Evolution of soil mineralogy}

The quantitative clay mineralogical composition allowed Dumon et al. (2014) to conclude that the parent material of both, bleached (weathered ash layer) and vertic (lacustrine deposit from the weathering of the volcanic rocks) horizons, must have been compositionally similar as their origin is from the same volcanic parent material. However the age of minerals formed and geochemical conditions controlling mineral formation in the two soil horizons are different; the lacustrine deposit being older with lower permeability relative to the ash layer deposited on top of it that is younger with higher permeability.

The observed differences in mineralogy of the bulk soil are for the most part the result of differences in the relative proportions of size fractions. The bleached E horizon is silty ( $71 \%$ of silt on average for the E horizon) while the vertic Bi horizon is clayey ( $68 \%$ clay on average for the Bi horizon). The mineralogy of the clay sub-fractions of both horizons is very similar, but differs in terms of relative proportions of the phases present in the bulk clay fraction (Table 2). Without taking into account the unanalyzed $0.05-0.2 \mu \mathrm{m}$ sub-fraction, the proportion of kaolinite layer types in the clay fraction is identical between $\mathrm{E}$ and $\mathrm{Bi}$ horizons: $38 \%$ and $39 \%$, respectively. Quantitative clay mineralogy 
Table 4

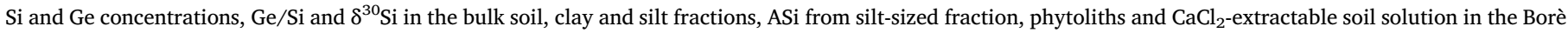
soil profile.

\begin{tabular}{|c|c|c|c|c|c|c|}
\hline & $\mathrm{Si}$ & $\mathrm{Ge}$ & $\mathrm{Ge} / \mathrm{Si}$ & 2SD & $\delta^{30} \mathrm{Si}$ & $2 S D$ \\
\hline & $\left(\mathrm{mmol} \mathrm{g}^{-1}\right)^{\mathrm{a}}$ & $\left(\mathrm{nmol} \mathrm{g}^{-1}\right)$ & $\left(\mu \mathrm{mol} \mathrm{mol}{ }^{-1}\right)$ & & $\%$ & \\
\hline Phytoliths (BSi) & 14.5 & 4.4 & 0.3 & 0.02 & 0.22 & 0.05 \\
\hline Granite-type bedrock $^{b}$ & 12.6 & 32.1 & 2.5 & 0.08 & -0.23 & 0.15 \\
\hline \multicolumn{7}{|l|}{ Bleached E horizon } \\
\hline Bulk soil & 13.0 & 18.0 & 1.4 & 0.06 & 0.40 & 0.18 \\
\hline Silt & 14.1 & 11.1 & 0.8 & 0.02 & 0.48 & 0.29 \\
\hline Clay & 11.3 & 44.9 & 4.0 & 0.10 & -0.69 & 0.03 \\
\hline $\mathrm{ASi}$ & 15.8 & 1.3 & 0.08 & 0.01 & 1.56 & 0.10 \\
\hline Soil solution $\left(\mathrm{mmol}^{-1}\right)$ & 0.2 & 0.06 & 0.3 & nd & 0.12 & 0.21 \\
\hline \multicolumn{7}{|l|}{ Vertic Bi horizon } \\
\hline Bulk soil & 10.1 & 45.9 & 4.6 & 0.12 & -0.57 & 0.32 \\
\hline Silt & 13.6 & 11.0 & 0.8 & 0.02 & 0.37 & 0.32 \\
\hline Clay & 9.4 & 59.1 & 6.3 & 0.14 & -1.41 & 0.02 \\
\hline $\mathrm{ASi}$ & 16.0 & 0.7 & 0.04 & 0.01 & 1.87 & 0.17 \\
\hline $\begin{array}{l}\text { Soil solution } \\
\qquad\left(\mathrm{mmol} \mathrm{l}^{-1}\right)\end{array}$ & 0.6 & 0.2 & 0.3 & 0.20 & 1.58 & 0.16 \\
\hline
\end{tabular}

a Except for soil solution, for which the unit is $\mathrm{mmol}^{-1}$

b $\mathrm{Ge} / \mathrm{Si}$ ratio from Cornelis et al. (2010) and $\delta^{30} \mathrm{Si}$ value from Savage et al. (2012) in granite-type unweathered bedrock. Ge/Si and $\delta^{30} \mathrm{Si}$ data from granite can be used as the equivalent for rhyolite parent material.

highlights that pedogenesis in the fine-textured Bi horizon implies dissolution of illite-type layers ( $9 \%$ of the analyzed clay fraction) and neoformation of smectite-type layers ( $52 \%$ of the analyzed clay fraction), compared to the coarser-textured $\mathrm{E}$ horizon where illite-type layers are still present (38\% of the analyzed clay fraction) and precipitation of smectite-type layers is less abundant ( $24 \%$ of the analyzed clay fraction). The fine-textured and older vertic soil material (Bi horizon) is therefore more concentrated in smectite resulting from illite dissolution and smectite precipitation than in the coarser-textured and younger bleached soil material (E horizon). However, the proportions of 1:1 (kaolinite) and 2:1 (illite and smectite) layer-type clay minerals are similar between topsoil $\mathrm{E}$ horizon and subsoil Bi horizon.

\section{2. $\delta^{30} \mathrm{Si}$ and $\mathrm{Ge} / \mathrm{Si}$ ratios variations in soils}

The silt-sized inorganic constituents, mainly amorphous silicates (volcanic glass and phytoliths), quartz and feldspars, are characterized by comparable $\mathrm{Si}$ isotopic and $\mathrm{Ge} / \mathrm{Si}$ geochemical signatures in both horizons (Fig. 2). This indicates that the primary minerals (Table 3) might have a similar geological origin, even if the depositional process and age of the $\mathrm{E}$ and $\mathrm{Bi}$ soil materials are different. This means that initial isotopic and geochemical signatures of silt-sized inorganic constituents cannot explain the different $\mathrm{Si}$ isotope signature of clay minerals between soil horizons with respect to variable primary mineral sources.

Bulk Bi soil material is relatively enriched in light ${ }^{28} \mathrm{Si}$ and $\mathrm{Ge}$ compared to E soil material (Fig. 2). As the silt fraction and ASi have similar $\delta^{30} \mathrm{Si}$ signatures, the lighter $\mathrm{Si}$ isotope composition in $\mathrm{Bi}$ soil material is explained by the significant higher content of clay-sized minerals. Indeed, the proportion of clay fraction in Bi horizon is higher and relatively more enriched in light ${ }^{28} \mathrm{Si}$ and Ge compared to claysized minerals in $\mathrm{E}$ horizon. The $\mathrm{Si}$ isotope difference between $\mathrm{CaCl}_{2}$ extractable solution and clay fraction $\left(\Delta^{30} \mathrm{Si}_{\text {solution-clay }}\right)$ is larger in the $\mathrm{Bi}$ than in the E horizon $(+2.99 \%$ for the Bi horizon and $+0.81 \%$ for the $\mathrm{E}$ horizon). This indicates that the formation of clay minerals governs the $\delta^{30} \mathrm{Si}$ and $\mathrm{Ge} / \mathrm{Si}$ variations in bulk soil, but also in the $\mathrm{CaCl}_{2}$-extractable solution. This also entails that for Bi horizon, greater depletion in light $\mathrm{Si}$ isotope in the $\mathrm{CaCl}_{2}$-extractable solution relative to clay

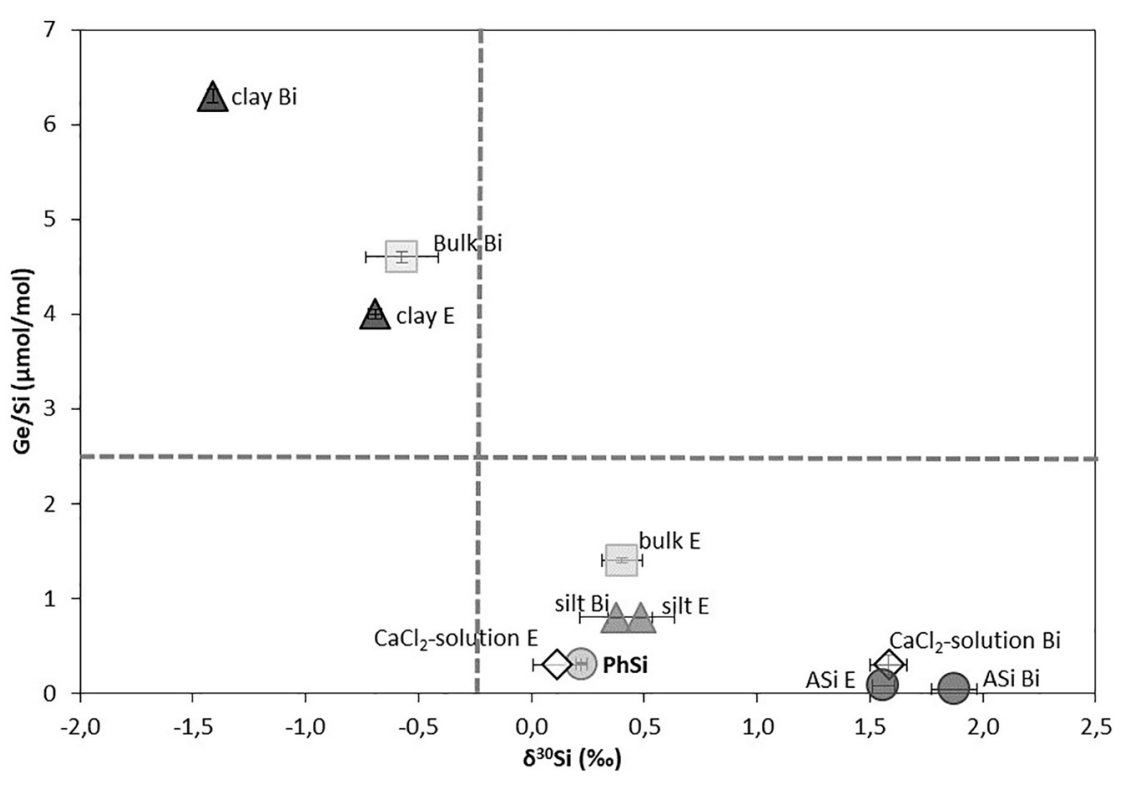

Fig. 2. Relationships between $\delta^{30} \mathrm{Si}$ values and Ge/Si ratios in bulk soil (squares), clay fraction (black triangles), silt fraction (grey triangles), soil amorphous silica (ASi; grey circles) plant ( $\mathrm{PhSi}$; grey circle) and $\mathrm{CaCl}_{2}$ - extractable solution (diamonds). Dashed lines are the $\mathrm{Si}$ isotope and $\mathrm{Ge} / \mathrm{Si}$ ratio signature of typical granite-type silicate rock signatures (Cornelis et al., 2010; Savage et al., 2012; Table 4). 


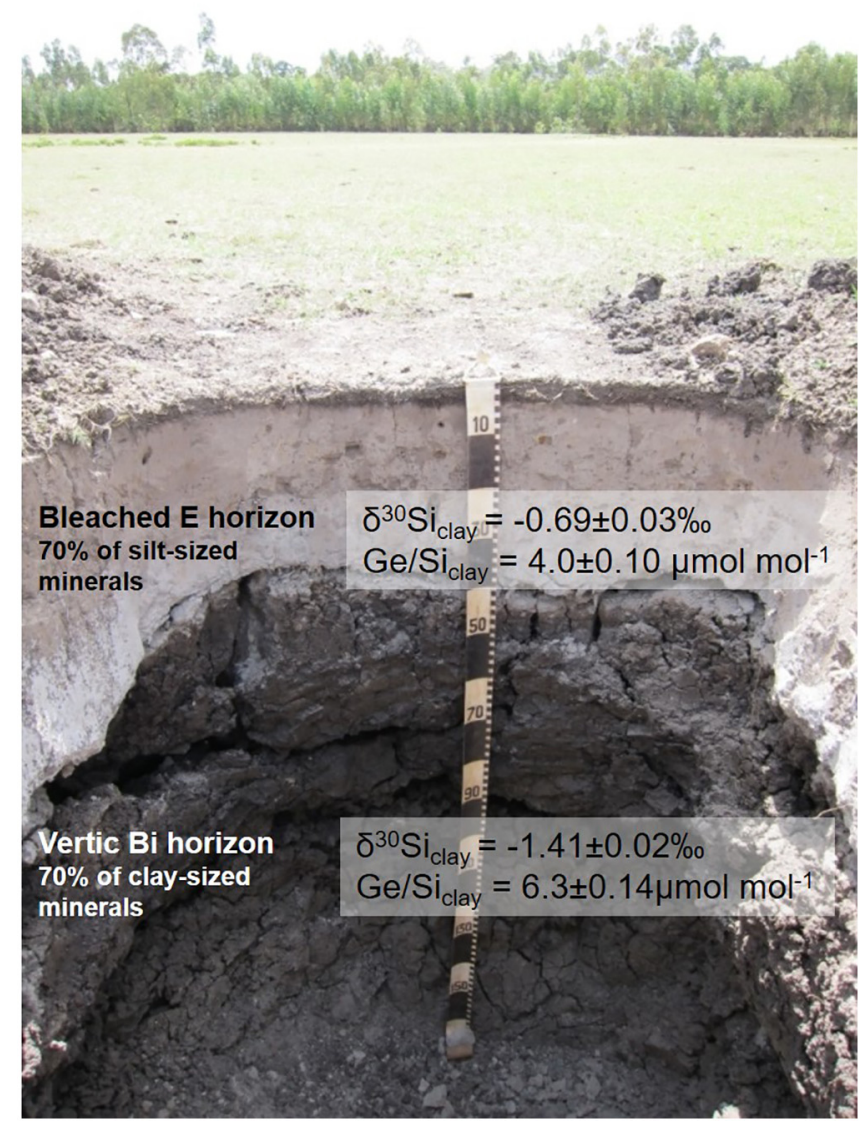

Fig. 3. Soil profile picture presenting the silty E horizon and clayey Bi horizon with their respective $\mathrm{Si}$ isotope signature and $\mathrm{Ge} / \mathrm{Si}$ ratio in the clay fraction.

fraction is partly controlled by ongoing process affecting clay mineral formation/dissolution.

\subsection{Geochemical conditions as a driver of solid-water interactions and resulting Si isotope signatures of pedogenic clay minerals}

The process of Si sorption onto Fe oxides must be investigated as it preferentially incorporates light $\mathrm{Si}$ isotopes (Delstanche et al., 2009). The dithionite-citrate-bicarbonate (DCB) selectively extracts free iron oxides in soils (Mehra and Jackson, 1960). DCB-extractable Si (1.2\% in E horizon and $1.0 \%$ in Bi horizon) represents between 2.4 and $4.1 \%$ of total Si concentration in bulk soil and is not related to DCB-extractable Fe in the E (1.0\%) and Bi (3.3\%) horizons (Cornelis et al., 2014b). This means that the part of Si adsorbed onto Fe oxides does not substantially affect $\mathrm{Si}$ isotopic signature of the clay fraction compared to the process of Si precipitation in phyllosilicates (Delstanche et al., 2009; Opfergelt et al., 2010). The results of mineralogical, geochemical and isotope analyses indicate that the primary source of $\mathrm{Si}$ and the relative proportions of 1:1 (kaolinite) and 2:1 (illite and smectite) layer types in the clay fraction (Table 2) are comparable in the silty E horizon and in the clayey Bi horizon. Furthermore, it is well known that strongly desilicated soils, characterized by enrichment of 1:1 (kaolinite) layer types relative to 2:1 layer types, will present the lower $\mathrm{Si}$ isotope ratios (Ziegler et al., 2005; Opfergelt et al., 2012; Opfergelt and Delmelle, 2012). It is therefore surprising to observe lighter $\delta^{30} \mathrm{Si}$ values in the clay fraction of Bi horizon compared to the clay fraction of $\mathrm{E}$ horizon for two soil horizons having similar proportions of 1:1 (kaolinite) and 2:1 (illite and smectite) layer types clay minerals. The Si isotope difference between solid and solution $\left(\Delta^{30} \mathrm{Si}_{\text {solid-solution }}\right)$ associated with primary mineral dissolution and precipitation of secondary phyllosilicate minerals is around $+2 \%$ o (Ziegler et al., 2005). However, the exact equilibrium and rate-dependent kinetic isotopic fractionations associated with dissolution/precipitation processes are still undetermined for 1:1 and 2:1 layer types clay minerals such as kaolinite, smectite and illite (Opfergelt and Delmelle, 2012; Frings et al., 2016). Given the lowest $\mathrm{Si}$ isotope ratio has been found in strongly desilicated soil enriched in kaolinite (Ziegler et al., 2005), we assume that the isotope fractionation factor associated with the dissolution of secondary illite minerals and precipitation of smectite minerals cannot explain such low $\delta^{30} \mathrm{Si}$ values for the bulk clay fraction in the Bi horizon $(-1.41 \%$ ) compared to E horizon ( $-0.69 \%$ ). The contrasting $\mathrm{Si}$ isotope and $\mathrm{Ge} / \mathrm{Si}$ composition of the clay fraction between the Bi and $\mathrm{E}$ horizons cannot, therefore, only be explained by lower content of illite-type minerals in Bi compared to E horizon and the associated fractionation factor during dissolution-precipitation reactions.

The lower $\delta^{30} \mathrm{Si}$ values and higher Ge/Si ratios in the clay fraction of the Bi horizon could be explained by different $\mathrm{Si}$ isotope fractionation factors between $\mathrm{E}$ and $\mathrm{Bi}$ horizons, i.e., different geochemical conditions favoring larger $\mathrm{Si}$ isotope fractionation during initial precipitation of clay minerals (kinetically-controlled fractionation) in one horizon relative to the other. In natural environments, the relative impact of equilibrium and kinetic isotope fractionation on $\mathrm{Si}$ isotope compositions measured are difficult to disentangle given that the equilibrium $\mathrm{Si}$ isotope fractionation factors between soil solution and solid phases are not known precisely. But kinetically-driven $\mathrm{Si}$ isotope fractionation factors are larger than $\mathrm{Si}$ isotope fractionation factors at equilibrium (Roerdink et al., 2015). The initial lacustrine environment of the $\mathrm{Bi}$ horizon is a confined area that concentrates the elements resulting in the accumulation of smectite-type minerals and formation of a vertic horizon in the current soil profile. The current higher Si concentration of $\mathrm{CaCl}_{2}$-extractable solution in vertic Bi horizon $\left(97.9 \mathrm{mg} . \mathrm{kg}^{-1}\right)$ re-

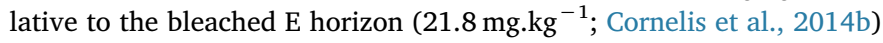
confirms the confined area less affected by desilication. Our results suggest that in that confined lacustrine environment, the higher Si concentrations in solution favored kinetically-dominated $\mathrm{Si}$ isotope fractionation during Si adsorption onto Al-hydroxide precursors (Oelze et al., 2014) and preferentially adsorbing light Si isotopes. The secondary precipitates formed from these precursors inherited a light $\mathrm{Si}$ isotope composition (Oelze et al., 2014; Roerdink et al., 2015). The resulting lower $\mathrm{Si}$ isotope ratio in solid secondary products from that low permeability environment has been preserved in inherited secondary precipitates in the Bi horizon of the current soil profile (Fig. 3).

Regarding modern processes in this soil profile, permeability conditions, controlled by the contrasting textural properties, sharply differ between the ash-layer environment that is characterized by an intense leaching of pore water (E horizon), and the lacustrine-layer environment that is characterized by a much lower rate of water percolation (Bi horizon) (Van Ranst et al., 2011). Lower percolation rates in the Bi horizon than in the $\mathrm{E}$ horizon can lead to differences in $\mathrm{Si}$ isotope fractionation factors associated with on-going processes of clay formation in the two soil horizons, depending on the relative proportion of kinetic vs. equilibrium fractionation (Oelze et al., 2014; Roerdink et al., 2015). This is illustrated by the $\mathrm{Si}$ isotope difference between the clay fraction and the $\mathrm{CaCl}_{2}$ solution $\left(\Delta^{30} \mathrm{Si}_{\text {solution-clay }}\right)$ in the two soil horizons: higher $\Delta^{30} \mathrm{Si}_{\text {solution-clay }}$ in the vertic Bi horizon $(-2.99 \%)$ than in the bleached $\mathrm{E}$ horizon $(-0.81 \%)$. In specific soil conditions characterized by long residence time of pore water such as in the Bi horizon, the $\mathrm{Si}$ isotope composition of the soil solution $\left(\mathrm{CaCl}_{2}\right.$-extractable) reflects ongoing soil processes that may be kinetically-driven (with larger $\mathrm{Si}$ isotope fractionation factors; Roerdink et al., 2015) and lead to higher $\delta^{30} \mathrm{Si}$ values in soil pore water of the Bi horizon $(+1.58 \%$ o compared to well-drained soil in E horizon $(+0.12 \% 0)$. In contrast in a well-drained soil environment such as the $\mathrm{E}$ horizon, pore water has lower ionic activity (lower $\mathrm{Si}$ concentration in $\mathrm{CaCl}_{2}$-extractable solution) implying soil conditions less favorable to kinetically-driven $\mathrm{Si}$ isotope fractionation, and a resulting limited $\mathrm{Si}$ isotope fractionation factor (Roerdink et al., 2015). 
The data highlights that residence time of pore water in soils is therefore a key factor that must be taken into account when using $\mathrm{Si}$ isotope signature of clay minerals to trace weathering processes.

\subsection{Implications for tracing soil-forming processes using stable Si isotopes}

Our study demonstrates that besides the known $\mathrm{Si}$ isotope fractionation factor associated with the dissolution of primary minerals and precipitation of secondary minerals, soil properties such as texture and permeability and resulting chemical composition of the solution must be taken into account when using $\mathrm{Si}$ isotope fractionation for tracing element pathways in water-soil-plant continuum.

Our results confirm that solid-water $\mathrm{Si}$ isotope fractionation associated with dissolution and precipitation of soil solid phases is systemdependent (Geilert et al., 2015). The different geochemical conditions likely drive solid-water interactions involving different regime for kinetic isotope fractionation. This means that identical clay mineralogy can be characterized by different $\mathrm{Si}$ isotope signatures depending on the geochemical conditions in which they were formed. Our results show that inheritance processes and the associated $\mathrm{Si}$ isotope signature of inherited clay minerals must be taken into account when using stable Si isotopes in terrestrial environments. This is in good agreement with recent findings showing that $\mathrm{Si}$ and $\mathrm{Li}$ isotope signatures of riverine sediments also integrate ancient and modern weathering processes (Zhang et al., 2017; Dellinger et al., 2017). The present study highlights the need to better understand how short-time and microscale soil processes, such as residence time of weathering solution in soil pore space, can affect dissolution/precipitation processes and the resulting Si isotope signature of clay minerals. This could also apply to microscale processes in pores of riverine and marine sediments. This is a time- and spatial-scale challenge allowing to better assess the controls of microscale physico-chemical processes in soils on variations of $\mathrm{Si}$ isotope signatures in land and oceans, as well land-ocean interfaces.

\section{Acknowledgments}

We thank V. Lai and M. Soon (UBC) for assistance with element analysis and K. Gordon and J. Barling (UBC) for assistance with Si isotopic analysis. We thank M. Brzezinski (University of California Santa Barbara) for providing us diatomite. J-T.C. and S.O. were supported by "Fonds National de la Recherche Scientifique" of Belgium. This research was also supported by the 'Soil Fertility Project' within the Institutional Co-operation Programme between the Flemish Interuniversity Council (VLIR) and the Jimma University of Ethiopia, as well by D.W. NSERC Discovery Grant.

\section{References}

Abraham, K., Opfergelt, S., Fripiat, F., Cavagna, A.-J., de Jong, J.T.M., Foley, S., André, L., Cardinal, D., 2008. $\delta^{30} \mathrm{Si}$ and $\delta^{29} \mathrm{Si}$ determinations on BHVO-1 and BHVO-2 reference materials via new configuration on Nu Plasma Multi Collector (MC)-ICP-MS. Geostand. Geoanal. Res. 32, 193-202.

Ameijeiras-Mariño, Y., Opfergelt, S., Schoonejans, J., Vanacker, V., Sonnet, P., De Jong, J., Delmelle, P., 2017. Impact of low denudation rates on soil chemical weathering intensity: a multiproxy approach. Chem. Geol. 456, 72-84.

Basile-Doelsch, I., Meunier, J.D., Parron, C., 2005. Another continental pool in the terrestrial silicon cycle. Nature 433, 399-402.

Bern, C.R., Brzezinski, M.A., Beucher, C., Ziegler, K., Chadwick, O.A., 2010. Weathering, dust, and biocycling effects on soil silicon isotope ratios. Geochim. Cosmochim. Acta 74, 876-889.

Berner, R.A., 1978. Rate control of mineral dissolution under earth surface conditions. Am. J. Sci. 278 (9), 1235-1252.

Bish, D.L., Von Dreele, R.B., 1989. Rietveld refinement of non-hydrogen atomic positions in kaolinite. Clay Clay Miner. 37, 289-296.

Bouchez, J., von Blanckenburg, F., Shuessler, J.A., 2013. Modeling novel stable isotope ratios in the weathering zone. Am. J. Sci. 313, 267-308.

Cardinal, D., Alleman, L.Y., De Jong, J., Ziegler, K., André, L., 2003. Isotopic composition of silicon measured by multicollector plasma source mass spectrometry in dry plasma mode. J. Anal. Atom. Spectrom. 18, 213-218.

Cardinal, D., Gaillardet, J., Hughes, H.J., Opfergelt, S., André, L., 2010. Contrasting silicon isotope signatures in rivers from the Congo Basin and the specific behaviour of organic-rich waters. Geophys. Res. Lett. 37, L12403.

Carpentier, M., Weis, D., Chauvel, C., 2013. Large U loss during weathering of upper continental crust: the sedimentary record. Chem. Geol. 340, 91-104.

Chadwick, O.A., Chorover, J., 2001. The chemistry of pedogenic thresholds. Geoderma $100,321-353$.

Christensen, B.T., 1992. Physical fractionation of soil and organic matter in primary particle size and density separates. In: Advances in Soil Science. Springer, pp. 1-90.

Cornelis, J.-T., Delvaux, B., Cardinal, D., André, L., Ranger, J., Opfergelt, S., 2010. Tracing mechanisms controlling the release of dissolved silicon in forest soil solutions using Si isotopes and Ge/Si ratios. Geochim. Cosmochim. Acta 74, 3913-3924.

Cornelis, J.-T., Delvaux, B., Georg, R.B., Lucas, Y., Ranger, J., Opfergelt, S., 2011. Tracing the origin of dissolved silicon transferred from various soil-plant systems towards rivers: a review. Biogeosciences 8, 89-112.

Cornelis, J.T., Weis, D., Lavkulich, L., Vermeire, M.-L., Delvaux, B., Barling, J., 2014a. Silicon isotopes record dissolution and reprecipitation of pedogenic clay minerals in a podzolic soil chronosequence. Geoderma 235-236, 19-29.

Cornelis, J.-T., Dumon, M., Tolossa, A.R., Delvaux, B., Deckers, J., Van Ranst, E., 2014b. The effect of pedological conditions on the sources and sinks of silicon in the Vertic Planosols in south-western Ethiopia. Catena 112, 131-138.

Dellinger, M., Bouchez, J., Gaillardet, J., Faure, L., Moureau, J., 2017. Tracing weathering regimes using the lithium isotope composition of detrital sediments. Geology 45, 411-414.

Delstanche, S., Opfergelt, S., Cardinal, D., Elsass, F., André, L., Delvaux, B., 2009. Silicon isotopic fractionation during adsorption of aqueous monosilicic acid onto iron oxide. Geochim. Cosmochim. Acta 73, 923-934.

Derry, L.A., Kurtz, A.C., Ziegler, K., Chadwick, O.A., 2005. Biological control of terrestrialsilica cycling and export fluxes to watersheds. Nature 433, 728-731.

Doebelin, N., Kleeberg, R., 2015. Profex: a graphical user interface for the Rietveld refinement program BGMN. J. Appl. Crystallogr. 48, 1573-1580.

Dumon, M., Tolossa, A.R., Capon, B., Detavernier, C., Van Ranst, E., 2014. Quantification of clay mineralogy of a Vertic Planosol in southwestern Ethiopia: impact on soil formation hypotheses. Geoderma 214, 184-196.

Engström, E., Rodushkin, I., Baxter, D.C., Öhlander, B., 2006. Chromatographic purification for the determination of dissolved silicon isotopic compositions in natural waters by high-resolution multicollector inductively coupled plasma mass spectrometry. Anal. Chem. 78, 250-257.

Frings, P.J., Clymans, W., Fontorbe, G., De La Rocha, C.L., Conley, D.J., 2016. The continental Si cycle and its impact on the ocean Si isotope budget. Chem. Geol. 425, 12-36.

Froelich, P.N., Andreae, M.O., 1981. The marine geochemistry of germanium: ekasilicon. Science 213, 205-207.

Geilert, S., Vroon, P.Z., Keller, N.S., Gudbrandsson, S., Stefánsson, A., 2015. Silicon isotope fractionation during silica precipitation from hot-spring waters: evidence from the Geysir geothermal field, Iceland. Geochim. Cosmochim. Acta 164, 403-427.

Georg, R.B., Reynolds, B.C., Frank, M., Halliday, A.N., 2006. New sample preparation techniques for the determination of Si isotopic compositions using MC-ICPMS. Chem. Geol. 235, 95-104.

Georg, R.B., Reynolds, B.C., West, A.J., Burton, K.W., Halliday, A.N., 2007. Silicon isotope variations accompanying basalt weathering in Iceland. Earth Planet. Sci. Lett. 261, 476-490.

Georg, R.B., Zhu, C., Reynolds, B.C., Halliday, A.N., 2009. Stable silicon isotopes of groundwater, feldspars, and clay coatings in the Navajo Sandstone aquifer, Black Mesa, Arizona, USA. Geochim. Cosmochim. Acta 73, 2229-2241.

Herbauts, J., Dehalu, F.A., Gruber, W., 1994. Quantitative determination of plant opal content in soils using a combined method of heavy liquid separation and alkali dissolution. Eur. J. Soil Sci. 45, 379-385.

IUSS Working Group WRB, 2015. World Reference Base for Soil Resources 2014. World Soil Resources Reports 106. FAO, Rome.

Kelly, E.F., 1990. Methods for extracting opal phytoliths from soil and plant material. In: Workshop on Biotic Indicators of Global Change, Seatlle, Washington.

Kleeberg, R., Monecke, T., Hillier, S., 2008. Preferred orientation of mineral grains in sample mounts for quantitative XRD measurements: how random are powder samples? Clay Clay Miner. 56, 404-415.

Kurtz, A.C., Derry, L.A., Chadwick, O.A., 2002. Germanium-silicon fractionation in the weathering environment. Geochim. Cosmochim. Acta 66, 1525-1537.

Jochum, K.P., Nohl, U., Herwig, K., Lammel, E., Stoll, B., Hofmann, A.W., 2005. GeoReM: a New Geochemical Database for Reference Materials and Isotopic Standards. Geostand. Geoanal. Res. 29, 333-338.

Lasaga, A.C., 1984. Chemical-kinetics of water-rock interactions. J. Geophys. Res. 89 (NB6), 4009-4025.

Lugolobi, F., Kurtz, A.C., Derry, L.A., 2010. Germanium-silicon fractionation in a tropical, granitic weathering environment. Geochim. Cosmochim. Acta 74, 1294-1308.

Maher, K., 2010. The dependence of chemical weathering rates on fluid residence time Earth Planet. Sci. Lett. 294, 101-110.

Mehra, O.P., Jackson, M.L., 1960. Iron Oxides Removal From Soils and Clays by Dithionite Citrate System Buffered With Sodium Bicarbonate. Clays and Clay Minerals. Proc. 7th. Pergamon Press, London, pp. 317-327.

Mortlock, R.A., Froelich, P.N., 1996. Determination of germanium by isotope dilutionhydride generation inductively coupled plasma mass spectrometry. Anal. Chim. Acta $322,5638-5645$.

Oelze, M., von Blanckenburg, F., Hoellen, D., Dietzel, M., Bouchez, J., 2014. Si stable isotope fractionation during adsorption and the competition between kinetic and equilibrium isotope fractionation: implications for weathering systems. Chem. Geol. $380,161-171$.

Oelze, M., von Blanckenburg, F., Bouchez, J., Hoellen, D., Dietzel, M., 2015. The effect of $\mathrm{Al}$ on $\mathrm{Si}$ isotope fractionation investigated by silica precipitation experiments. Chem. 
Geol. 397, 94-105.

Opfergelt, S., Delmelle, P., 2012. Silicon isotopes and continental weathering processes: assessing controls on Si transfer to the ocean. Compt. Rendus Geosci. 344, 723-738.

Opfergelt, S., Cardinal, D., André, L., Delvigne, C., Bremond, L., Delvaux, B., 2010. Variations of $\delta^{30} \mathrm{Si}$ and $\mathrm{Ge} / \mathrm{Si}$ with weathering and biogenic input in tropical basaltic ash soils under monoculture. Geochim. Cosmochim. Acta 74, 225-240.

Opfergelt, S., Georg, R.B., Burton, K.W., Guicharnaud, R., Siebert, C., Gislason, S.R., Halliday, A.N., 2011. Silicon isotopes in allophane as a proxy for mineral formation in volcanic soils. Appl. Geochem. 26, S115-S118.

Opfergelt, S., Georg, R.B., Delvaux, B., Cabidoche, Y.M., Burton, K.W., Halliday, A.N., 2012. Silicon isotopes and the tracing of desilication in volcanic soil weathering sequences, Guadeloupe. Chem. Geol. 326-327, 113-122.

Opfergelt, S., Cornelis, J.-T., Houben, D., Givron, C., Burton, K.W., Mattielli, N., 2017a The influence of weathering and soil organic matter on $\mathrm{Zn}$ isotopes in soils. Chem. Geol. 446, 140-148.

Opfergelt, S., Williams, H.M., Cornelis, J.-T., Guicharnaud, R.A., Georg, R.B., Siebert, C., Gislason, S.R., Halliday, A.N., Burton, K., 2017b. Iron and silicon isotope behavior accompanying weathering in Icelandic soils, and the implications for iron export from peatlands. Geochim. Cosmochim. Acta 217, 273-291.

Pogge von Strandmann, P.A.E., Opfergelt, S., Lai, Y.-J., Sigfusson, B., Gislason, S.R. Burton, K., 2012. Lithium, magnesium and silicon isotope behavior accompanying weathering in a basaltic soil and pore water profile in Iceland. Earth Planet. Sci. Lett. $339,11-23$.

Poitrasson, F., Viers, J., Martin, F., Braun, J.-J., 2008. Limited iron isotope variations in recent lateritic soils from Nsimi, Cameroon: implications for the global Fe geochemical cycle. Chem. Geol. 253, 54-63.

Pretorius, W., Weis, D., Williams, G., Hanano, D., Kieffer, B., Scoates, J., 2006. Complete trace elemental characterization of granitoid (USGS G-2, GSP-2) reference materials by high resolution inductively coupled plasma-mass spectrometry. Geostand. Geoanal. Res. 30, 39-54.

Reynolds, B.C., 2011. In: Baskaran, M. (Ed.), Handbook of Environmental Isotope Geochemistry, Advances in Isotope Geochemistry. Springer-Verlag Berlin Heidelberg, pp. 2011. https://doi.org/10.1007/978-3-642-10637-8_6.

Reynolds, B.C., Aggarwal, J., André, L., Baxter, D., Beucher, C., Brzezinski, M.A. Engström, E., Georg, B., Land, M., Leng, M.J., Opfergelt, S., Rodushkin, I., Sloane, H.J., Van den Boorn, S.H.J.M., Vroon, P.Z., Cardinal, D., 2007. An inter-laboratory comparison of Si isotope reference materials. J. Anal. Atom. Spectrom. 22, 561-568.

Roerdink, D.L., van den Boorn, S.H.J.M., Geilert, S., Vroon, P.Z., van Bergen, M.J., 2015. Experimental constraints on kinetic and equilibrium silicon isotope fractionation during the formation of non-biogenic chert deposits. Chem. Geol. 402, 40-51.

Sauer, D., Saccone, L., Conley, D.J., Herrmann, L., Sommer, M., 2006. Review of methodologies for extracting plant available and amorphous Si from soils and aquatic sediments. Biogeochemistry 80, 89-108.

Savage, P.S., Georg, R.B., Williams, H.M., Turner, S., Halliday, A.N., Chappell, B.W., 2012. The silicon isotope composition of granites. Geochim. Cosmochim. Acta 92 184-202.

Scarlett, N.V.Y., Madsen, I.C., 2006. Quantification of phases with partial or no known crystal structures. Powder Diffract. 21, 278-284.

Schudel, G., Lai, V., Gordon, K., Weis, D., 2015. Trace element characterization of USGS reference materials by HR-ICP-MS and Q-ICP-MS. Chem. Geol. 410, 223-236.

Scribner, A.M., Kurtz, A.C., Chadwick, O.A., 2006. Germanium sequestration by soil: targeting the roles of secondary clays and Fe-oxyhydroxides. Earth Planet. Sci. Lett. 243, 760-770.

Stamm, F.M., Zambardi, T., Chmeleff, J., Schott, J., von Blanckenburg, F., Oelkers, E. 2019. The experimental determination of equilibrium $\mathrm{Si}$ isotope fractionation factors among $\mathrm{H}_{4} \mathrm{SiO}_{4}{ }^{\circ}, \mathrm{H}_{3} \mathrm{SiO}_{4}$, and amorphous silica $\left(\mathrm{SiO}_{2} \cdot 0.32 \mathrm{H}_{2} \mathrm{O}\right)$ at 25 and $75^{\circ} \mathrm{C}$ using the three-isotope method. Geochim. Cosmochim. Acta 255, 49-68.

Steinhoefel, G., Breuer, J., von Blanckenburg, F., Horn, I., Kaczorek, D., Sommer, M. 2011. Micrometer silicon isotope diagnostics of soils by UV femtosecond laser ablation. Chem. Geol. 286, 280-289.

Sverdrup, H., 1996. Geochemistry, the key to understanding environmental chemistry. Sci. Total Environ. 183, 67-87.

Tadesse, S., Milesi, J.P., Deschamps, Y., 2003. Geology and mineral potential of Ethiopia: a note on geology and mineral map of Ethiopia. J. Afr. Earth Sci. 36, 273-313.

Ufer, K., Roth, G., Kleeberg, R., Stanjek, H., Dohrmann, R., Bergmann, J., 2004. Description of X-ray powder pattern of turbostratically disordered layer structure with a Rietveld compatible approach. Z. Krist.-Crystal. Mater. 219, 519-527.

Urey, H.C., 1947. The thermodynamic properties of isotopic substances. J. Chem. Soc. $562-581$.

Van Ranst, E., Dumon, M., Tolossa, A.R., Cornelis, J.T., Stoops, G., Vandenberghe, R.E., Deckers, J., 2011. Revisiting ferrolysis processes in the formation of planosols for rationalizing the soils with stagnic properties in WRB. Geoderma 163, 265-274.

Vandevenne, F.I., Delvaux, C., Hughes, H., André, L., Ronchi, B., Clymans, W., Barao, L., Cornélis, J.-T., Govers, G., Meire, P., Struyf, E., 2015. Landscape cultivation alters $\delta^{30} \mathrm{Si}$ signature in terrestrial ecosystems. Sci. Rep. 5, 7732.

Wilson, S.A., 1997. Data Compilation for USGS Reference Material BHVO-2. U.S. Geological Survey Open-File Report, Hawaiian Basalt.

Zhang, X., Pringle, E., Dellinger, M., Bouchez, J., Gaillardet, J., Moynier, F., 2017. Silicon Isotopes in Large River Sediments: Imprint of Modern-Day Weathering vs. Continental Recycling. Goldschmidt conference Abstracts. vol. A. pp. 4496.

Ziegler, K., Chadwick, O.A., Brzezinski, M.A., Kelly, E.F., 2005. Natural variations of $\delta^{30} \mathrm{Si}$ ratios during progressive basalt weathering, Hawaiian Islands. Geochim. Cosmochim. Acta 69, 4597-4610. 